\title{
AL-IQTISHADIYAH
}

Jurnal Ekonomi Syariah dan Hukum Ekonomi Syariah

E-ISSN: 2621-0274; P-ISSN: 2442-2282

Volume 6, Nomor 2, Desember 2020

\section{ANALISIS PENGARUH MARKETING MIX TERHADAP MINAT MASYARAKAT MEMBELI SUKUK}

\author{
Erdinda Santoso ${ }^{1} \&$ Rachma Indra Rini ${ }^{2}$
}

Fakultas Ekonomi Islam, Universitas Negeri Surabaya, Indonesia. E-mail: erdindasantoso16081194018@mhs.unesa.ac.id ${ }^{1}$; rachmaindrarini@unesa.ac.id ${ }^{2}$

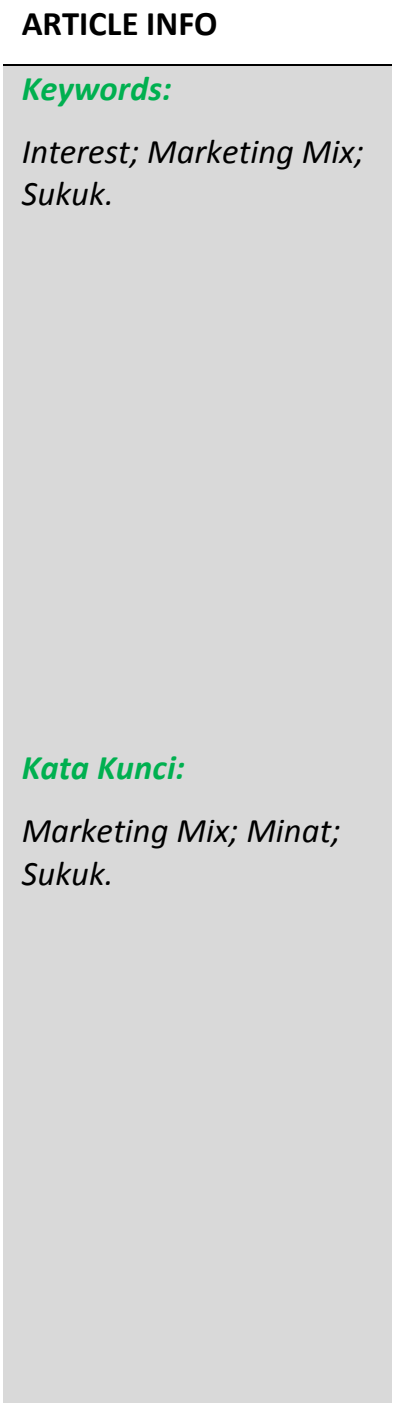

\begin{abstract}
The purpose of this research is to understand the effect of the marketing mix, namely product, price, place, and promotion on people's interest in buying Sukuk. The marketing mix used in this research is only 4Ps because Sukuk is a product, not a service. This research is a quantitative research with Accidental Sampling sampling technique. The research sample was 100 respondents from the Surabaya community who had income. This research uses logistic regression analysis techniques through the SPSS program. The results of this research show that simultaneously product, price, place, and promotion have a positive effect on people's interest in buying Sukuk. While partially, the result shows that product and price variables have a significant and positive effect. In conclusion, of the four variables that affect people's interest in buying Sukuk, only two variables are product and price variables.
\end{abstract}

\section{ABSTRAK}

Maksud dari penelitian ini untuk memahami pengaruh marketing mix yaitu produk, harga, tempat, dan promosi terhadap minat masyarakat untuk membeli Sukuk. Marketing mix yang digunakan dalam penilitian ini hanya Product, Place, Price, Promotion karena Sukuk merupakan suatu produk bukan berupa layanan jasa. Penelitian ini termasuk penelitian kuantitatif dengan teknik pengambilan sampel Accidental Sampling. Sampel penelitian sebanyak 100 responden masyarakat Surabaya yang telah berpenghasilan. Riset ini memakai teknik analisis regresi logistik melalui progam SPSS. Hasil riset ini memperlihatkan secara simultan produk, harga, tempat, dan promosi berpengaruh secara positif terhadap minat masyarakat untuk membeli Sukuk. Sedangkan secara parsial, diperoleh hasil bahwa variabel produk dan harga berpengaruh signifikan dan positif. Kesimpulannya dari empat variabel tersebut yang berpengaruh terhadap minat masyarakat untuk membeli Sukuk hanya dua varaibel yaitu variabel produk dan harga.

\section{Pendahuluan}

Pasar modal menjadi asal mula pendanaan untuk perusahaan dan media investasi bagi para pemodal. Tanggal 03 Juli 1997 awal mula pasar modal diterbitkan oleh PT. Danareksa Investment Management. Menurut Undang-undang Nomor 8 Tahun 1995 
tentang Pasar Modal (UUPM) pasar modal syariah bukanlah suatu sistem yang terpisah dari sistem pasar modal secara keseluruhan. Definisi pasar modal syariah diatur dalam UUPM namun sesuai dengan prinsip syariah. Oleh karena itu pasar modal syariah bukanlah suatu sistem yang terpisah darai sistem pasar modal secara keseluruhan. Definisi pasar modal menurut Undang-undang Nomor 8 Tahun 1995 tentang Pasar Modal (UUPM) adalah kegiatan yang bersangkutan dengan penawaran dan perdagangn efek, Perusahaan Publik yang berkaitan dengan efek yang diterbitkannya, serta lembaga dan profesi yang berkaitan dengan efek.

Otoritas Jasa Keuangan telah menjadi destination statement 2017 dan juga sebagai regulator yang mengawasi industri keuangan nasional, yaitu "Menjadi lembaga profesional dalam pengaturan dan pengawasan sektor jasa keuangan yang terintegrasi, guna mewujudkan pasaar keuangan yang dalam (financial market deepening) dan inklusif, serta terdepan dalam sistem perlindungan konsumen keuangan dan masyarakat, untuk mendukung terciptanya sistem keuangan yang stabil dan berkelanjutan"1. Oleh karena itu Otoritas Jasa Keuangan mengeluarkan peraturan mengenai pasar modal syariah yang diatur dalam POJK Nomor. 15/POJK.04/2015 tentang penerapan prinsip syariah di pasar modal.

Pasar modal bertujuan untuk meningkatkan pembangunan di Indonesia. Hal ini dilakukan agar terjadinya pemerataan dan pertumbuhan stabilitas ekonomi yang nantinya mengaruh kepada kesejahteraan masyarakat. Berpartisipasi dalam salah satu destinasi financial market dapat dilakukan untuk mengembangkan pasar modal syariah. Pasar modal memiliki produk investasi syariah yang terdiri dari sukuk, reksadana syariah, dan saham syariah. Selama ini perkembangan produk pasar modal syariah masih realtif kecil daripada pasar modal konvensional.

Banyak cara untuk meningkatkan perkembangan pasar modal syariah di Indonesia. Progam peningkatan jumlah supply dan demand produk pasar modal merupakan strategi yang dapat dilakukan untuk mengembangkan pasar modal syariah. Dari sisi supply, menurut Otoritas Jasa Keuangan perlu adanya progam yang sumber pendanaannya berasal dari sukuk atau saham syariah dengan cara mendesak perusahaan untuk menerbitkannya. Perlu juga melakukan progam yang mendesak manajer investasi untuk mengeluarkan reksadana syariah. Sedangkan dari sisi demand, membutuhkan progam-progam yang memukau investor ${ }^{2}$. Dengan begitu investor akan berinvestasi pada produk pasar modal syariah. Dengan beberapa strategi tersebut diharapkan nantinya dapat mengalami kenaikan produk syariah dan juga penyebaran investor, yang nantinya membuat pasar modal syariah lebih stabil dan berkembang.

Sukuk di Indonesia ada 2 jenis yaitu Sukuk Korporasi dan Sukuk Pemerintah. Sukuk Korporasi diterbitkan oleh suatu perusahaan dan Sukuk Pemerintah diterbitkan oleh

\footnotetext{
${ }^{1}$ Direktorat Pasar Modal Syariah, 2015. Roadmap Pasar Modal Syariah. Jakarta: Otoritas Jasa Keuangan. HIm, 26

${ }^{2}$ Direktorat Pembiayaan Syariah, 2017. Investasi Syariah Melalui Surat Berharga Syariah Negara (Sukuk Negara). Jakarta: Kementerian Keuangan. HIm, 11
} 
Kementerian Keuangan. Sukuk merupakan bagian dari instrumen keuangan syariah yang banyak dibicarakan baik domestik maupun internasional. Sukuk banyak dibicarakan oleh masyarakat dikarenakan sukuk salah satu cara investasi yang mudah dan tidak harus mengeluarkan banyak uang untuk memulai berinvestasi. Selain itu dengan berinvestasi sukuk juga dapat membantu pemerintah untuk melakukan pembangunan negara. Sukuk dikembangkan untuk menciptakan sumbersumber bagi pembiayaan Anggaran Pendapatan Belanja Negara (APBN). Selain untuk pembiayaan APBN sukuk digunakan untuk membiayai pembangunan proyek negara. Proyek yang dimaksud adalah proyek sektor energi, telekomunikasi, perhubungan, pertanian, dan industri manufaktur perumahan. Hal tersebut diatur dalam Undangundang No. 19 Tahun 2008. Proyek-proyek tersebut biasa disebut dengan Project Financing Sukuk yang merupakan Sukuk Negara untuk menyelenggarakan kegiatan/proyek Pemerintah tertentu yang sudah didistribusikan ke dalam APBN (earnmarket).

Sukuk dikelola oleh Pemerintah lebih tepatnya Kementerian Keuangan Republik Indonesia. Untuk menunjang pengembangan pasar dalam negeri, pemerintah telah mengesahkan Undang-undang tentang Surat Berharga Syariah Negara (SBSN) yaitu UU. No. 19 Tahun 2008. Selain itu Dewan Syariah Nasional juga mengeluarkan fatwa tentang Sukuk yaitu fatwa nomor 32/DSN-MUI/IX/2002. Undang-undang Surat Berharga Syariah Negara diterbitkan untuk menjadi pegangan penerbitan Sukuk.

Pada tahun 2009 Kementerian Keuangan Republik Indonesia pertama kali menerbitkan Sukuk Ritel atau biasa disebut dengan SR dengan nama SR001. Pada awal pendiriannya ini terdapat sebanyak 13 agen penjual Sukuk Ritel. Sampai saat ini Kemenkeu RI telah menerbitkan serti SR 011. Agen penjual ritel juga bertambah menjadi 22 agen yang terdiri dari 17 bank konvensional, 3 bank syariah, dan 2 perusahaan sekuritas. Penerbitan Sukuk ini mendapat respon positif dari masyarakat, karena hanya dengan minimal pembelian Rp. 1.000.000 sudah dapat berinvestasi Sukuk. Dengan begitu masyarakat juga sudah membantu pemerintah untuk pembangunan nasional. Pemerintah sempat mengadakan pengekangan untuk investor kelas besar yang membeli Sukuk Ritel. Pemerintah sudah menyiapkan Sukuk IFR (Ijara Fixed Rate) dengan pembelian paling sedikit $1 \mathrm{M}$.

Selain Sukuk yang dikelola oleh pemerinntah ada juga Sukuk yang dikeluarkan oleh suatu perusahaan yang bisa disebut dengan Sukuk Korporasi. Tujuan suatu perusahaan mengeluarkan Sukuk demi memperoleh pendanaan dari masyarakat. Selain anggaran internal perusahaan atau anggaran dengan meminjam bank, perusahaan menggunakan Sukuk ini untuk mengembangkan bisnis perusahaan. Pada tahun 2002 perusahaan perdana di Indonesia yang mengeluarkan Sukuk Korporasi adalah PT. Indosat Tbk dengan tingkat imbal hasil 16,75\%. Terdapat 23 perusahaan sudah menerbitkan Sukuk di Indoensia hingga tahun 2019 dengan jumlah Sukuk sedang berkisar 123 Sukuk Korporasi.

Menurut Otoritas Jasa Keuangan perkembangan Sukuk Korporasi mengalami peningkatan dari tahun ke tahun. Dari tahun 2014 sebesar Rp. 17.500 Miliar hingga tahun 2019 sebesar Rp. 50.000 Miliar. Hal ini menunjukan perkembangan Sukuk di 
Indonesia mengalami pertumbuhan yang baik. Walaupun dinilai memiliki perkembangan yang mengalami peningkatan setiap tahun, perkembangan Sukuk di Indonesia dapat dikategorikan lambat. Menurut data Kementerian Keuangan Republik Indonesia tahun 2015 Malaysia memiliki market share terbesar dari total outstanding Sukuk di dunia yaitu sebesar $67 \%$ dari global outstanding Sukuk. Sedangkan Indonesia memiliki nilai oustanding sebesar 34\% dari global outstanding, tentunya ini perbedaan yang sangat jauh. Banyak tantangan yang dihadapi dalam pengembangan Sukuk di Indonesia, salah satunya adalah minat masyarakat untuk tertarik produk Sukuk dan kemudian menjadi investor.

Banyak faktor yang mempengaruhi minat pengambilan keputusan untuk memutuskan berinvestasi, khususnya pada Sukuk. Ini dilihat dari beberapa penelitian terdahulu. Beberapa peneliti juga pernah meneliti tentang faktor-faktor yang mempengaruhi minat masyarakat untuk membeli sukuk. Menurut penelitian terdahulu oleh Suratna tahun 2015, faktor inflasi dan kurs tidak mempengaruhi penjualan Sukuk Ritel 005 di Pasar Modal Syariah. Kemudian menurut Moch Chambali tahun 2010, minat masyarakat untuk berinvestasi ditentukan oleh risiko investasi dan atribut instrumen islami. Selain itu berdasarkan hasil analisis asumsi klasik dan analisis regresi linear sederhana yang dilakukan oleh Rizki Chaerul Pajar membuktikan bahwa motivasi investasi dan pengetahuan tentang investasi dapat mempengaruhi minat mahasiswa FE UNY untuk berinvestasi di pasar modal. Menurut Lilis (2011) salah satu instrument keuangan syariah yang diterbitkan oleh negara atau korporasi adalah sukuk atau obligasi syariah ${ }^{3}$. Penelitiannya membahas tentang apa saja faktor resiko yang mempengaruhi minat publik terhadap investasi Sukuk Islam SR001. Perbedaan dengan penelitian ini adalah dalam penelitian ini membahas tentang apa saja yang mempengaruhi minat masyarakat untuk berinvestasi sukuk. Sukuk disini sukuk secara keseluruhan baik sukuk yang dikeluarkan oleh negara atau korporasi

Banyaknya fenomena tersebut maka penulis tertarik untuk meneliti lebih lanjut mengenai minat masyarakat terhadap sukuk. Penelitian ini berbeda dari penelitian yang lain yaitu penulis melihat dari segi marketing mix. Marketing mix tentunya juga menjadi salah satu faktor yang dapat mempengaruhi masyarakat untuk membeli sukuk. Marketing mix merupakan faktor yang paling penting dalam pemasaran suatu produk. Hal tersebut dikarenakan keuntungan atau keberhasilan suatu produk dapat diterima oleh masyarakat dapat dilihat dari bagaimana suatu perusahaan dapat memasarkan produk dengan baik. Jika perusahaan memiliki produk yang bagus namun dari segi pemasarannya kurang baik, maka masyarakat belum tentu tahu produk yang bagus tersebut. Namun bisa juga ada banyak faktor lain yang mempengaruhi minat untuk berinvestasi sukuk, maka hal ini perlu untuk diteliti agar lebih mengetahui lagi apa yang selama ini dipertimbangkan masyarakat untuk melakukan pembelian investasi sukuk.

\footnotetext{
${ }^{3}$ Lilis. (2011). Faktor-Faktor Yang Mempengaruhi Minat Masyarakat Berinvestasi Sukuk. Jurnal Walisongo, Vol 19, No. 1, hlm 1
} 


\section{Landasan Teori}

\subsection{Sukuk}

Menurut Ali (2000) pengertian Sukuk secara etimologi yaitu sukuk berasal dari kata "Sakk" yang berarti dokumen atau sertifikat. Sedangkan Sukuk merupakan istilah dalam bahasa Arab yang merupakan bentuk jamak. Sakk adalah buku yang mencatat kegiatan transaksi. Kitab Mu'jam Al Mustholahaat Al Iqtishodiyah Wal Islamiyah megartikan sakk sebagai surat berharga. Sedangkan menurut The Accounting and Auditting Organisation for Islamic Financial Institutions (AAOIFI) Sukuk merupakan bukti kepemilikan yang tidak dibagikan atas suatu aset atau kegiatan investasi tertentu, bukti ini berupa sertifikat.

\subsection{Minat}

Menurut Slameto, minat merupakan rasa menyukai atau suatu rasa yang menunjukkan ketertarikan terhadap sesuatu atau kegiatan, tanpa adanya paksaan atau intruksi dari orang lain ${ }^{4}$. Sedangkan menurut Nugroho, minat beli adalah proses pengintegrasian yang mengkombinasikan pengetahuan untuk mengevaluasi dua atau lebih perilaku alternatif dan memilih salah satu diantaranya. Dalam penelitian ini indikator minat terdiri dari minat dan tidak minat, karena dalam penelitian ini menggunakan regresi logistik.

\subsection{Marketing Mix}

Jerome McCarthy dikenal sebagai bapak marketing mix. Jerome McCarthy yang menemukan konsep 4P yaitu Product, Price, Place. Konsep inilah yang kemudian dikenal oleh masyarakat sehingga sering menjadi rujukan jika membahas tentang marketing mix.

a. Product

Produk menjadi hal yang utama dalam marketing mix, karena dapat mempengaruhi strategi pemasaran lainnya. Produk yang akan dipilih lalu dihasilkan dan dipasarkan tentunya akan menentukan kegiatan promosi yang dibutuhkan, serta penentuan harga dan cara penyalurannya.

Produk adalah bentuk penawaran perusahaan untuk mencapai tujuan perusahaan melalui pemuasan kebutuhan dan keinginan pelanggan ${ }^{5}$. Produk dapat berupa barang dan jasa yang ditawarkan kepada pelanggan potensial untuk memenuhi kebutuhan dan keinginan tertentu.

b. Price

Menentukan harga pada suatu produk tentu sangat penting, terutama pada keadaan semakin ketatnya persaingan yang semakin tajam dan perkembangan permintaan. Persaingan yang sangat ketat ini membuat konsumen akan

\footnotetext{
${ }^{4}$ Slameto, 2010. Belajar dan Faktor-faktor Yang Mempengaruhinya. Jakarta: Rineka Cipta. HIm, 22

${ }^{5}$ Tjiptono, F. (2014). Pemasaran Jasa: Prinsip, Penerapan, Penerapan dan Penelitian. Yogyakarta: Andi. HIm, 20
} 
mengambil keputusan untuk memilih harga yang rendah diantara persaingan yang ada. Oleh karena itu penetapan harga sangat penting untuk menjaga dan meningkatkan posisi perusahaan dipasar yang tercemin dalam target pasar. Selain itu penetapan harga juga mampu mempengaruhi kemampuan bersaing perusahaan.

Dalam menetapkan harga, perlu diperhatikan faktor-faktor yang mempengaruhinya, baik langsung maupun tidak langsung. Faktor yang mempengaruhi secara langsung adalah harga bahan baku, biaya produksi, biaya pemasaran, adanya peraturan pemerintah, dan faktor lainnya. Sedangkan faktor yang tidak langsung namun erat hubungannya dengan penetapan harga adalah produk sejenis yang dijual oleh para pesaing dan potongan (discount) untuk penyalur dan konsumen.

c. Place

Lokasi atau tempat seringkali ikut menentukan kesuksesan perusahaan. Sebelum memulai sebuah usaha perusahaan harus menentukan lokasi yang strategis agar mudah dijangkau konsumen. Disamping itu, lokasi juga berpengaruh terhadap dimensi-dimensi strategi seperti flexibility, competitive, positioning, dan focus. Fleksibilitas suatu lokasi merupakan ukuran sejauh mana suatu perusahaan dapat bereaksi terhadap perubahan situasi ekonomi. Keputusan pemilihan lokasi berkaitan dengan komitmen jangka panjang terhadap perubahan situasi ekonomi. Keputusan pemilihan lokasi berkaitan dengan komitmen jangka panjang terhadap aspek-aspek yang sifatnya kapital intensif, maka perusahaan benar-benar harus mempertimbangkan dan menyeleksi lokasi yang responsif terhadap situasi ekonomi, demografi, budaya, dan persaingan di masa mendatang.

d. Promotion

Promosi merupakan faktor yang paling penting untuk menentukan berhasil atau tidak suatu progam pemasaran. Jika produk yang dihasilkan sudah memiliki kualitas yang bagus, namun apabila konsumen belum mengetahui atau mendengar tentang produk tersebut maka mereka tidak akan mengambil keputusan untuk membelinya.

Ada tiga macam alat atau sarana promosi yang dapat digunakan untuk melakukan kegiatan promosi: ${ }^{6}$

1) Periklanan (adversiting)

Iklan merupakan sarana yang digunakan untuk menginformasikan, menarik, dan mempengaruhi konsumen untuk membeli suatu produk. Promosi dengan iklan dapat dilakukan dengan berbagai media seperti: televisi, koran, majalah, dan lainnya.

\footnotetext{
${ }^{6}$ Kasmir. (2014). Manajemen Perbankan. Jakarta: PT RajaGrafindo Persada. HIm, 14
} 
2) Publisitas (publicity)

Publisitas merupakan sarana promosi yang digunakan untuk menarik konsumen melalui kegiatan seperti pameran, bakti sosial, seminar, perlombaan, dan lainnya.

3) Penjualan Pribadi (personal selling)

Penjualan perorangan melibatkan pembicaraan langsung antara penjual dan pelanggan potensial. Penjualan tatap muka ini menyediakan umpan balik segera yang membantu wiraniaga untuk menyesuaikan diri.

\section{Metode Penelitian}

Penelitian ini menggunakan jenis penelitian secara kuantitatif dengan pendekatan asosiatif. Pendekatan asosiatif merupakan penelitian yang bertujuan untuk mengetahui pengaruh ataupun hubungan antara dua variabel atau lebih. Penelitian ini untuk mengetahui pengaruh marketing mix dengan minat masyarakat untuk membeli sukuk.

Pengumpulan data dan informasi yang diperoleh dalam penelitian menggunakan data primer dan data sekunder. Teknik yang digunakan untuk mengumpulkan data primer yaitu dengan menyebarkan kuisioner kepada masyarakat Surabaya yang telah berpenghasilan. Selain itu data primer ini juga seputar harga, produk, promosi, dan tempat tentang Sukuk. Teknik yang digunakan untuk mendapatkan data sekunder yaitu dilakukan dengan metode studi perpustakaan (library research). Misalnya seperti buku-buku literature, jurnal, atau data-data dari penelitian terdahulu.

Populasi yang digunakan semua masyarakat di Surabaya yang telah memiliki penghasilan. Masyarakat Surabaya yang telah berpenghasilan diatas 5 juta rupaih. Kriteria tersebut digunakan karena masyarakat Surabaya memiliki UMK sebesar Rp. 4.200.000. Selain itu masyarakat yang memiliki penghasilan diatas 5 juta rupiah tentunya mereka sudah memenuhi kebutuhan hidupnya dan akan menyisihkan sebagian penghasilan untuk berinvestasi. Menurut Badan Pusat Statistik Kota Surabaya jumlah masyarakat yang telah bekerja pada tahun 2019 sebesar 1.474.934 jiwa. Accidental Sampling digunakan sebagai teknik sampling dalam penelitian ini. Sampel dalam penelitian ini sebesar 99,99 responden atau dibulatkan menjadi 100 responden. Penentuan jumlah sampel menggunkaan rumus Slovin yang dijelaskan sebagai berikut ini:

$$
\mathrm{n}=\frac{N}{1+N e^{2}}
$$

Keterangan:

$\mathrm{n} \quad$ = Jumlah sampel

$\mathrm{N}=$ Jumlah populasi

$e \quad=$ Batas toleransi kesalahan (10\%) 
Berdasarkan rumus diatas besarnya sampel dalam penelitian ini adalah :

$$
\begin{gathered}
n=\frac{1.474 .934}{1+1.474 .934(0.1)^{2}} \\
n=99,99
\end{gathered}
$$

Lokasi penelitian ini dilaksanakan di seluruh wilayah Kota Surabaya. Pemilihan lokasi tersebut dikarenakan Kota Surabaya sebagai kota Metropolis dan menjadi kota terbesar kedua setelah Jakarta. Beradasarkan data Kustodian Sentral Efek Indonesia (KSEI) pada tahun 2019 Jawa Timur menduduki posisi keempat jumlah investor terbanyak, yang didominasi investor di kota Surabaya.

Penelitian ini menggunakan analisis regresi logistik. Regresi logistik berbeda dengan regresi linear lainnya karena dalam regresi logistik variabel dependen berupa kategori yang biasanya 0 dan 1 . Variabel dependen dalam penelitian ini bersifat non metrik yaitu dengan menggunakan dummy (minat dan tidak minat) sedangkan variabel independen yang digunakan bersifat metrik. Rumus regresi logistik yang dipakai pada penelitian ini yaitu ini:

$Y=\beta 0+\beta 1 X 1+\beta 2 X 2+\beta 3 X 3+\beta 4 X 4+e$

Keterangan :

$\begin{array}{ll}Y & =\text { Minat } \\ \beta 0 & =\text { Konstan } \\ \beta 1-\beta 4 & =\text { Koeifisien } \\ \text { X1 } & =\text { Produk } \\ \text { X2 } & =\text { Harga } \\ \text { X3 } & =\text { Promosi } \\ X 4 & =\text { Tempat } \\ e & =\text { error }\end{array}$

\section{Hasil dan Pembahasan}

Deskripsi karakteristik bersumber pada jenis kelamin, usia, pendidikan terakhir, agama, domisili, KTP, jenis pekerjaan, dan pendapatan. Responden di dominasi oleh laki-laki sebanayk 52 responden, selain itu responden dalam penelitian ini di dominasi usia $>51$ tahun sebanyak 31 orang. Pendidikan terakhir di dominasi S1/S2/S3 sebanyak 62 orang, selain itu pekerjaan responden dalam penelitian ini didominasi oleh pegawai swasta sebanayk 44 responden. Pendapatan responden di dominasi dengan pendapatan 5-6 juta rupaih per bulan sebanyak 56 responden. Tentunya responden dalam penelitian in berdomisili dan ber KTP Surabaya. 


\subsection{Pengaruk Produk Terhadap Minat Masyarakat Untuk Membeli Sukuk}

Hasil penelitian untuk variabel produk memperlihatkan bahwa (P-value) sebesar 0,002 . Nilai tersebut lebih kecil dari nilai signifikan 0,05 . Sehingga variabel produk berpengaruh terhadap minat masyarakat untuk membeli Sukuk. Hal ini menunjukkan bahwa masyarakat memperhatikan produk yang ada pada Sukuk sebelum akhirnya memutuskan untuk minat membeli Sukuk. Selain itu masyarakat juga mengetahui dan menganggap produk Sukuk memiliki variasi dan kualitas produk yang baik. Dapat dilihat bahwa produk yang memiliki kualitas baik maka minat masyarakat untuk membeli Sukuk semakin besar. Konsumen akan merasa puas jika suatu produsen memiliki produk yang baik, maka dari itu mengembangkan dan mempertahankan kualitas produk yang sudah ada harus dilakukan oleh produsen.

Penelitian ini sesuai dengan hasil penelitian Faradiba yang menunjukkan nilai (Pvalue) variabel produk $0,001<0,05$. Artinya variabel produk mempengaruhi minat beli ulang konsumen. ${ }^{7}$

Produk harus mengutamakan kualitas dan mutu dari produk yang dihasilkan, selain itu produk harus halal dan terbebas dari unsur riba, gharar, dan maysir. Sebagaimana dalam surah Al-Baqarah ayat 168 berikut ini :

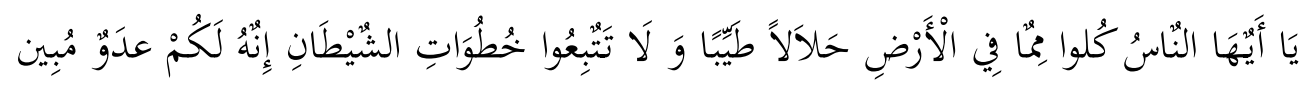

Artinya : "Hai sekalian manusia, makanlah yang halal lagi baik dari apa yang terdapat di bumi, dan janganlah kamu mengikuti langkah-langkah syaiton; karena sesungguhnya syaiton itu adalah musuh yang nyata bagimu."

Produk Sukuk tidak mengandung unsur riba didalamnya, ini juga sesuai dengan hasil penelitian, bhawa banyak masyarakat yang mengeathui bahwa produk Sukuk tidak mengandung riba.

\subsection{Pengaruh Harga Terhadap Minat Masyarakat Untuk Membeli Sukuk}

Hasil penelitian untuk variabel harga memperlihatkan bahwa ( $P$-value) sebesar 0,015. Nilai tersebut lebih kecil dari nilai signifikan 0,05. Maka variabel harga mempengaruhi minat masyarakat untuk membeli Sukuk. Kondisi tersebut memperlihatkan masyarakat memperhatikan harga Sukuk yang ditawarkan sebelum akhirnya memutuskan untuk minat membeli Sukuk. Selain itu masyarakat juga menganggap harga Sukuk masih terjangkau dan sesuai dengan besaran kupon yang ditawarkan. Jika harga yang ditawarkan terjangkau tentunya ini akan meningkatkan minat masyarakat untuk membeli Sukuk. Minat masyarakat dapat dipengaruhi oleh kesesuaian harga dengan produk yang didapat. Minat masyarakat akan meningkat jika harga yang didapat sesuai dengan kualitas produk. Karena masyarakat memperhatikan kesesuaian antara harga dan produk.

\footnotetext{
${ }^{7}$ Faradiba, 2013. Analisis Pengaruh Kualitas Produk, Harga, Lokasi Dan Kualitas Pelayanan Terhadap Minat Beli Ulang Konsumen. DIPONEGORO JOURNAL OF MANAGEMENT. HIm, 6
} 
Penelitian ini sesuai dengan hasil penelitian oleh Silaningsih dan Utami yang menunjukkan bahwa nilai (P-value) variabel harga $0,000<0,05$. Artinya variabel harga mempengaruhi minat beli konsumen pada UMKM produk olahan makanan ringan.Penentuan harga dalam islam yaitu harga tidak boleh terlalu tinggi dan tidak boleh terlalu rendah yang dapat merugikan salah satu pihak lain. Sebagaimana hadist Nabi Muhammad yang artinya:

"Sesungguhnya Allah SWT yang maha menetapkan harga, yang maha memegang yang maha melepas dan memberi rezeki dan sesungguhnya aku berharap bertemu dengan Allah dalam keadaan tidak seorang pun dari kalian menuntut aku karena perbuatan zalim terhadap jiwa atau tentang harga (barang-barang)."

Harga Sukuk sendiri telah sesuai dengan aturan yang telah dikeluarkan oleh Kementerian Keuangan dan Otoritas Jasa Keuangan. Harga Sukuk juga terjangkau dan dapat di beli oleh masyarakat dengan mudah.

\subsection{Pengaruh Tempat Terhadap Minat Masyarakat Untuk Membeli Sukuk}

Hasil penelitian untuk variabel tempat memperlihatkan bahwa ( $P$-value) sebesar 0,421 . Nilai tersebut lebih besar dari nilai signifikan 0,005 . Sehingga variabel tempat tidak berpengaruh terhadap minat masyarakat untuk membeli Sukuk. Hal ini menunjukkan bahwa masyarakat tidak memperhatikan tempat untuk minat membeli Sukuk. Walaupun begitu masyarakat menilai bahwa tempat untuk membeli dan menjual Sukuk mudah dijangkau dan berada di tempat yang strategis. Meskipun akses jalur tempat sudah termasuk ramai dan mudah dijangkau oleh masyarakat, namun hal tersebut tidak membuat masyarakat antusias untuk datang kembali. Masyarakat lebih memilih menggunakan fasilitas melalui internet yang dapat di akses di smartphone. Adanya teknologi yang semakin canggih membuat masyarakat lebih memilih untuk mengakses melalui smartphone.

Penelitian ini sesuai dengan hasil penelitian oleh Jayabaya yang menunjukkan bahwa nilai ( $P$-value) variabel tempat $0,090>0,05$. Artinya variabel tempat tidak mempengauhi minat penggunaan kereta api melalui aplikasi mobile KAI ACCESS.

\subsection{Pengaruh Promosi Terhadap Minat Masyarakat Untuk Membeli Sukuk}

Hasil penelitian untuk variabel promosi memperlihatkan bahwa (P-value) sebesar 0,131 . Nilai tersebut lebih besar dari nilai signifikan 0,05 . Sehingga variabel promosi tidak berpengaruh terhadap minat masyarakat. Hal ini menunjukkan bahwa masyarakat merasa promosi tentang Sukuk masih sangat kurang. Masyarakat merasa belum memiliki informasi mengenai produk secara informatif, selain itu sumber informasi belum cukup tersedia. Minat masyarakat dapat ditingkatkan dengan memberikan informasi yang informatif terhadap suatu produk agar masyarakat mengetahui lebih tentang keunggulan produk tersebut. 
Penelitian ini sesuai dengan hasil penelitian oleh Guntur yang menunjukkan nilai (Pvalue) $0,217>0,05$. Artinya variabel promosi tidak berpengaruh terhadap minat beli. ${ }^{8}$

Promosi sendiri merupakan sarana komunikasi bagi perusahaan baik perusahaan dagang maupun jasa untuk memperkenalkan produk yang mereka tawarkan. Selain itu promosi juga sebagai media silahturahmi antara perusahaan dan konsumen. Promosi didalam islam tidak dibenarkan apabila terdapat hal-hal yang dilebihlebihkan dan terdapat unsur penipuan yang dapat merugikan orang lain. Sesuai dengan firman Allah SWT pada Surah Al-Syu'ara ayat 183:

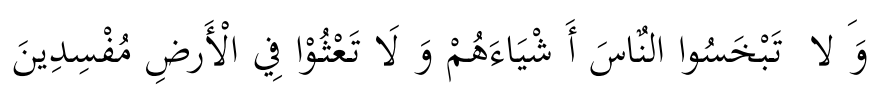

Artinya : "Dan janganlah kamu merugikan manusia pada hak-haknya dan janganlah kamu merajalela di muka bumi dengan membuat kerusakan."

\subsection{Pengaruh Variabel Produk, Harga, Tempat, dan Promosi Terhadap Minat Masyarakat Untuk Membeli Sukuk}

Hasil uji omnibus memperlihatkan bahwa variabel produk, harga, tempat, dan promosi berpengaruh secara simultan terhadap minat masyarakat membeli Sukuk, Sehingga dapat dinyatakan bahwa hipotesis dalam penelitian diterima. Hasil penelitian tersebut dilihat dari nilai nilai ( $P$-value) adalah sebesar 0,000 . Nilai tersebut lebih kecil dari nilai signifikan yaitu sebesar 0,05 sehingga $\mathrm{HO}$ ditolak dan $\mathrm{H} 1$ diterima.

Berdasarkan hasil uji omnibus dan pembahasan hasil penelitian terdahulu, maka bisa dinyatakan bahwa variabel produk, harga, tempat, dan promosi secara serentak mempengaruhi minat masyarakat untuk membeli Sukuk. Namun hasil pengujian Nagelkerke R Square menunjukkan angka sebesar 0,660 yang dapat diartikan bahwa minat masyarakat untuk membeli Sukuk sebesar $66 \%$ diperngaruhi oleh variabel produk, harga, tempat, dan promosi. Presentase lainnya sebesar $34 \%$ dipengaruhi oleh variabel lain yang tidak terdapat di pembahasan pada penelitian ini.

\section{Penutup}

Bersumber pada riset sudah dijelaskan empat variabel yang terdiri dari produk, harga, tempat, dan promosi yang mempengaruhi minat adalah variabel produk dan variabel harga. Variabel produk mempengaruhi minat sesuai dengan hasil penelitian Faradiba dan variabel harga mempengaruhi minat sesuai dengan hasil penelitian Silaningsih \& Utami. Selain itu variabel produk, harga, tempat, dan promosi secara simultan berpengaruh dalam mempengaruhi minat masyarakat untuk membeli Sukuk. Saran untuk peneliti selanjutnya adalah meneliti tentang perbedaan atau

\footnotetext{
${ }^{8}$ Guntur, P. M., 2013. Pengaruh Strategi Bauran Pemasaran Tabungan E'Batarapos Terhadap Minat Beli (Studi : Bank BTN KC Bandung). Sigma-MU, 5(2). HIm, 8
} 
perbandingan investasi Sukuk dengan investasi yang lainnya. Penelitian tersebut nantinya dapat menjadi referensi untuk calon investor.

\section{DAFTAR PUSTAKA}

AAOIFI, 2015. Shari'ah Standards. Bahrain: Accounting And Auditing Organization For Islamic Financial Institutions.

Angrum Pratiwi, D. M. (2017). Peran Sukuk Negara dalam Pembiayaan Infrastruktur. Al-Tijary Jurnal Ekonomi dan Bisnis Islam Vol. 2, No. 2, 155-176

Direktorat Pasar Modal Syariah, 2015. Roadmap Pasar Modal Syariah. Jakarta: Otoritas Jasa Keuangan.

Direktorat Pembiayaan Syariah, 2017. Investasi Syariah Melalui Surat Berharga Syariah Negara (Sukuk Negara). Jakarta: Kementerian Keuangan.

Faradiba, 2013. Analisis Pengaruh Kualitas Produk, Harga, Lokasi Dan Kualitas Pelayanan Terhadap Minat Beli Ulang Konsumen. DIPONEGORO JOURNAL OF MANAGEMENT.

Fatah, D. A. (2011). Perkembangan Obligasi Syariah (Sukuk) di Indonesia : Analisis Peluang dan Tantangan. Al'Adalah Vol. X, No. 1, 36.

Ghozali, 2011. Aplikasi Analisis Multivariate dengan Progam SPSS. Semarang: Badan Penerbit Universitas Diponegoro.

Ghozali. (2011). Aplikasi Analisis Multivariate dengan Progam SPSS. Semarang: Badan Penerbit Universitas Diponegoro.

Guntur, P. M., 2013. Pengaruh Strategi Bauran Pemasaran Tabungan E'Batarapos Terhadap Minat Beli (Studi : Bank BTN KC Bandung). Sigma-MU, 5(2).

Jayabaya, P., 2018. Pengaruh Penerapan Bauran Pemasaran Digital Terhadap Minat Beli Pengguna Kereta Api Melalui Aplikasi Mobile KAI ACCESS. Jurnal Riset Bisnis dan Manajemen.

Kasmir. (2014). Manajemen Perbankan. Jakarta: PT RajaGrafindo Persada.

Lilis. (2011). Faktor-Faktor Yang Mempengaruhi Minat Masyarakat Berinvestasi Sukuk. Jurnal Walisongo, Vol 19, No. 1

Malik, A. D. (2017). Analisa Faktor-Faktor Yang Mempengaruhi Minat Masyarakat Berinvestasi di Pasar Modal Syariah Melalui Bursa Galeri Investasi UISI. Jurnal Ekonomi dan Bisnis Islam, Vol 3, No. 1, 61-68.

Rahmi, H. (2017). Faktor-faktor yang Mempengaruhi Pengambilan Keputusan Petani Terhadap Penggunaan Benih Padi Di Kecamatan Nsam Kabupaten Aceh Utara. Agrifo, Vol. 2 No 2.

Sarah, A. P. (2014). Analisis faktor yang memengaruhi minat investor terhadap sukuk negara ritel. Institut pertanian bogor, 1-5. 
Silaningsih\&Utami, 2018. Pengaruh Marketing Mix Terhadap Minat Beli Konsumen Pada Usaha Mikro Kecil dan Menengah (UMKM) Produk Olahan Makanan Ringan. Jurnal Social Humanivora.

Slameto, 2010. Belajar dan Faktor-faktor Yang Mempengaruhinya. Jakarta: Rineka Cipta.

Sugiyono. (2014). Metode Penelitian Kuantitaif, Kualitatif, dan R\&D. Bandung: Alfabeta.

Suradi. (2012). Faktor-Faktor Yang Mempengaruhi Minat Beli Konsumen Terhadap Produk Tepung Sagu. Merbau.

Tjiptono, F. (2014). Pemasaran Jasa: Prinsip, Penerapan, Penerapan dan Penelitian. Yogyakarta: Andi.

Widyaningrum, N. A. (2017). Dampak Bauran Pemasaran Terhadap Minat Beli. PERFORMA: Jurnal Manajemen dan Start-Up Bisnis.

Yuliati, L. (2011). Faktor-faktor Yang Mempengaruhi Minat Masyarakat Berinvestasi Sukuk. Walisongo, Volume 19, Nomor 1, 104-106. 